\title{
Communication strategies of the nursing team in the aphasia after cerebrovascular accident*
}

\author{
ESTRATÉGIAS DE COMUNICAÇÃO DA EQUIPE DE ENFERMAGEM NAAFASIA \\ DECORRENTE DE ACIDENTE VASCULAR ENCEFÁLICO
}

\section{ESTRATEGIAS DE COMUNICACIÓN DEL EQUIPO DE ENFERMERÍA EN LAAFASIA SECUNDARIA A ACCIDENTE CEREBROVASCULAR}

\author{
Regina Cláudia Silva Souza', Edna Apparecida Moura Arcuri²
}

\begin{abstract}
This is an exploratory, cross-sectional study of quantitative design that aimed to identify the communication strategies used and reported by the nursing staff in the care of aphasic patients after a stroke. The techniques used were the participant observation and interviews with 27 subjects of the nursing staff of neurological units in a general hospital. The most frequently mentioned strategies were gestures (100\%), verbal communication (33.3\%), written communication (29.6\%) and the touch (18.5\%). Among the observed strategies, the gestures reached $40.7 \%$ and the touch was present in all situations, given its instrumental character essential to care. The findings show lack of knowledge of nonverbal, proxemics, kinesics and tacesics communication. No significant differences were observed among the professional categories depending on the length of experience with respect to the strategies reported by members of the nursing staff in the care for aphasic patients.
\end{abstract}

\section{DESCRIPTORS}

Stroke

Aphasia

Communication

Nursing, team

Nurse-patient relations

\section{RESUMO}

Estudo exploratório, transversal, de delineamento quantitativo, cujo objetivo foi identificar estratégias de comunicação referidas e usadas pela equipe de enfermagem durante o cuidado de pacientes afásicos após acidente vascular encefálico. Foram utilizadas a técnica de entrevista e a observação participante com 27 sujeitos da equipe de enfermagem de unidades neurológicas de um hospital geral. As estratégias mais referidas foram os gestos (100\%), a comunicação verbal $(33,3 \%)$, a comunicação escrita (29,6 \%) e os toques (18,5\%). Entre as estratégias observadas, os gestos atingiram $40,7 \%$ e o toque esteve presente em todas as situações, dado seu caráter instrumental imprescindível aos cuidados. Os achados indicam desconhecimento da comunicação não verbal, proxêmica, cinésica ou tacêsica. Não foram observadas diferenças significativas entre as categorias profissionais em função do tempo de experiência com respeito às estratégias referidas pelos membros da equipe de enfermagem para cuidar do paciente afásico.

\section{DESCRITORES}

Acidente vascular cerebral

Afasia

Comunicação

Equipe de enfermagem

Relações enfermeiro-paciente

\section{RESUMEN}

Estudio exploratorio de corte transversal, cuantitativo, cuyo objetivo fue identificar estrategias de comunicación utilizadas por el equipo de enfermería en el cuidado de pacientes afásicos después de un accidente cerebrovascular. Se utilizaron las técnicas de entrevistas y de observación participante en 27 sujetos del equipo de enfermería de unidades de neurología de un hospital general. Las estrategias más referidas fueron gestos $(100 \%)$, comunicación verbal $(33,3 \%)$, comunicación escrita $(29,6 \%)$ y los toques $(18,5 \%)$. Entre las estrategias observadas, los gestos alcanzaron el 40,7 $\%$ y el toque estaba presente en todas las situaciones dado su carácter instrumental esencial para cuidar. Los resultados indican un desconocimiento de la comunicación no verbal, proxémica, kinésica o háptica. No se observaron diferencias significativas entre las categorías profesionales en función del tiempo de experiencia con respecto a las estrategias mencionadas por los miembros del personal de enfermería para el cuidado de los pacientes con afasia.

\section{DESCRIPTORES}

Accidente cerebrovascular

Afasia

Comunicación

Grupo de enfermería

Relaciones enfermero-paciente

\footnotetext{
* Article extracted from the Master thesis "Communication strategies of the nursing team in aphasia after cerebrovascular accident" ${ }^{1}$ Regina Cláudia Silva Souza. Master in Nursing, Universidade de Guarulhos, Guarulhos, SP, Brazil. ${ }^{2}$ Edna Aparecida Moura Arcuri. Full Professor, Universidade de Guarulhos, Guarulhos, SP, Brazil. 


\section{INTRODUCTION}

Cerebrovascular accident (CVA) is a chronic disease with high incidence nowadays, constituting a major public health problem ${ }^{(1)}$. Data resulting from the epidemiological profile estimate that in 2015, CVA will reach 6.3 million people in the world, with significant impact on health care $\operatorname{costs}^{(2)}$. The disease causes cognitive, motor, communication and emotional sequelae ${ }^{(3)}$, which has repercussions in various aspects of life of people affected by it, also involving their families. Among those impairments, there is aphasia, a communication deficit that affects the use and understanding of language ${ }^{(4)}$ and reaches between 21 and $38 \%$ of patients who have suffered a CVA ${ }^{(5)}$. It is often associated with depression ${ }^{(6)}$, by negatively influencing the activities of daily living and independence, for which communication is key.

Therapeutic communication with aphasic patients is considered an essential element in care and is linked to the results of nursing assistance, positively influencing the relationships between professionals, patients and families. Health professionals should be prepared to use this type of communication, which aims to use the skill and knowledge of this area to help people with temporary physical limitations to adapt to a new phase of life ${ }^{(6)}$. It is believed that such adaptation influences the emotional conditions and recovery time, reducing the hospitalization period.

The types of communication in this condition are classified according to the resources used and with the purpose of establishing a definition to facilitate its understanding among professionals. Thus, kinesics communication refers to movement (gestures), tacesics to touch and proxemics to the proximity of bodies, all included in nonverbal communication.

Nurse practitioners remain close to patients who suffered a CVA most of their shift time because they need to perform many procedures. These professionals show difficulties when caring for patients with aphasia. Communication is inexpressive, not therapeutic and without any trace of empathy. The use of appropriate communication strategies is essential in the care, because it promotes safety and satisfaction ${ }^{(7)}$.

Aphasia leaves patients vulnerable to high risks of poor outcomes of care because of adverse events, limitations or inability to express their needs and grievances related to health care. In a recent Canadian study, aphasic patients had worse outcomes on quality of life when compared to patients in other conditions, revealing the negative impact of aphasia on their independence, social relationships and their living environment. Therefore, the ability of therapeutic communication is essential for the nursing professional, and it may be a key intervention to improve the quality of life of these people. Future studies should be carried out to confirm this hypothesis. Thus, understanding the aspects related to this issue becomes crucial in helping to picture the current conditions of care and the perceptions of those involved, as this constitutes an important gap in the area of assistance.

This study aimed to describe the communication strategies used and reported by members of the nursing staff in the care for patients after CVA.

\section{METHOD}

A cross-sectional study that used interviews to obtain information on the used strategies and field observations to verify its application in the nursing care provided by these same interviewed subjects. The design is considered quantitative because the recorded data in the field diary were categorized, quantified and treated quantitatively. Data were collected on inpatient units that provide care for neurological patients in a general hospital in São Paulo.

The study was approved by the Ethics and Research Committee with protocol number 505-09. The sample consisted of 27 subjects (six nurses, 11 technicians and ten nursing assistants), which represented $69 \%$ of the nursing staff of the units where the study was carried out. Professionals working in direct patient care who agreed to participate in the study were included. Those who were on vacation, sick leave or who performed administrative activities were excluded. After preliminary contacts for recruitment, individual appointments were scheduled to arrange the interviews and sign the Consent Form.

The first author of the study carried out the data collection in two phases: $1^{\text {st }}$ - Semi-structured interviews with each subject in a reserved spot in the neurology clinic at a previously scheduled time during their working hours. It was used a form that contained demographic and professional data, as well as closed and open questions about the strategies. $2^{\text {nd }}$ - The same subjects were observed while providing nursing care. A field diary was used, together with the reference script prepared by the researcher, which included key aspects of the strategies to be followed. Observation was made mainly in the morning, when most nursing care is performed. Communication strategies and attitudes of the participants during such care were recorded in the field diary.

The data were classified into qualitative variables that were statistically analyzed by absolute and relative frequencies, and into quantitative variables that were analyzed by the Fisher's exact test.

\section{RESULTS}

\section{Sociodemographic characteristics}

The mean age of the 27 participants of the study was 34 years \pm 8.4 and $55.2 \%$ of the sample was younger than 35 years. Among these, $55.5 \%$ had more than five years of experience with patients who had suffered a CVA. Regarding 
the time since graduation, on average it was 7.8 years \pm 6.0 and the time caring for patients with CVA was 4.8 years \pm 3.7 .

No statistically significant differences were observed among the professional groups $(p>0.05)$ on the mentioned strategies. The absence of reference of touching by nurses is noteworthy. The predominant type of communication were the gestures, pen and paper, and verbal communication.

It can be seen in Table 2 that the strategies reported by participants in relation to length of professional experience showed no significant differences between the more and less experienced. In both groups, the touch reached the highest frequencies, having been reported by all respondents. It draws the attention that the use of pen and paper and drawl were reported only by individuals with less experience, reaching a third of them. Low frequencies are apparent in most of these strategies.

Figure 1 displays the differences between the strategies according to the data collection techniques used and shows consistent use of nonverbal communication, based on the observation made.

Table 1 - Communication strategies reported by the nursing team professionals - São Paulo, SP, Brazil, 2010

\begin{tabular}{|c|c|c|c|c|c|c|c|}
\hline \multirow{3}{*}{ Strategies } & \multicolumn{6}{|c|}{ Professional training } & \multirow{3}{*}{ p-value } \\
\hline & \multicolumn{2}{|c|}{ nurse technician } & \multicolumn{2}{|c|}{ nursing assistant } & \multicolumn{2}{|c|}{ nurse } & \\
\hline & $\mathbf{n}$ & $\%$ & $\mathbf{n}$ & $\%$ & $\mathbf{n}$ & $\%$ & \\
\hline verbal communication & 6 & $54.50 \%$ & 2 & $20.00 \%$ & 1 & $16.70 \%$ & 0.151 \\
\hline touching & 1 & $9.10 \%$ & 4 & $40.00 \%$ & - & - & 0.079 \\
\hline painful stimuli & 1 & $9.10 \%$ & - & - & - & - & $* * *$ \\
\hline gestures & 11 & $100.00 \%$ & 10 & $100.00 \%$ & 6 & $100.00 \%$ & $* * *$ \\
\hline paper and pen & 1 & $9.10 \%$ & 5 & $50.00 \%$ & 2 & $33.30 \%$ & 0.119 \\
\hline caregivers & - & - & 1 & $10.00 \%$ & 2 & $33.30 \%$ & 0.111 \\
\hline nonverbal communication & - & - & 1 & $10.00 \%$ & - & - & 0.414 \\
\hline board & 1 & $9.10 \%$ & 2 & $20.00 \%$ & - & - & 0.45 \\
\hline alphabet & - & - & 2 & $20.00 \%$ & - & - & 0.159 \\
\hline drawl & 3 & $27.30 \%$ & 2 & $20.00 \%$ & - & - & 0.38 \\
\hline observation of the patient & - & - & 1 & $10.00 \%$ & 2 & $33.30 \%$ & 0.111 \\
\hline $\begin{array}{l}\text { use of terms easy to } \\
\text { understand }\end{array}$ & 1 & $9.10 \%$ & 1 & $10.00 \%$ & - & - & 0.732 \\
\hline proximity & 1 & $9.10 \%$ & - & - & - & - & 0.47 \\
\hline
\end{tabular}

Table 2 - Communication strategies mentioned by participants in relation to time of professional experience - São Paulo, SP, Brazil, 2010

\begin{tabular}{|c|c|c|c|c|c|}
\hline \multirow{2}{*}{$\begin{array}{l}\text { Communication } \\
\text { strategies }\end{array}$} & \multicolumn{2}{|c|}{ up to 5 years } & \multicolumn{2}{|c|}{ more than 5 years } & \multirow{2}{*}{ p-value } \\
\hline & $\mathbf{n}$ & $\%$ & $\mathbf{n}$ & $\%$ & \\
\hline verbal communication & 2 & 16.7 & 7 & 46.7 & $0.217^{*}$ \\
\hline touching & 2 & 16.7 & 3 & 20 & $>0.999 *$ \\
\hline painful stimuli & - & - & 1 & 6.7 & $* * *$ \\
\hline gestures & 12 & 100 & 15 & 100 & $* * *$ \\
\hline paper and pen & 4 & 33.3 & 4 & 26.7 & $>0.999 *$ \\
\hline caregivers & 1 & 8.3 & 2 & 13.3 & $>0.999 *$ \\
\hline nonverbal communication & 1 & 8.3 & & & $* * *$ \\
\hline board & 1 & 8.3 & 2 & 13.3 & $>0.999 *$ \\
\hline alphabet & 1 & 8.3 & 1 & 6.7 & $>0.999 *$ \\
\hline drawl & 4 & 33.3 & 1 & 6.7 & $0.139 *$ \\
\hline observation of the patient & 1 & 8.3 & 2 & 13.3 & $>0.999 *$ \\
\hline $\begin{array}{l}\text { use of terms easy to } \\
\text { understand }\end{array}$ & 2 & 16.7 & - & - & $0.188^{*}$ \\
\hline proximity & 1 & 8.3 & - & - & $* * *$ \\
\hline speak up & 1 & 8.3 & 1 & 6.7 & $>0.999 *$ \\
\hline
\end{tabular}




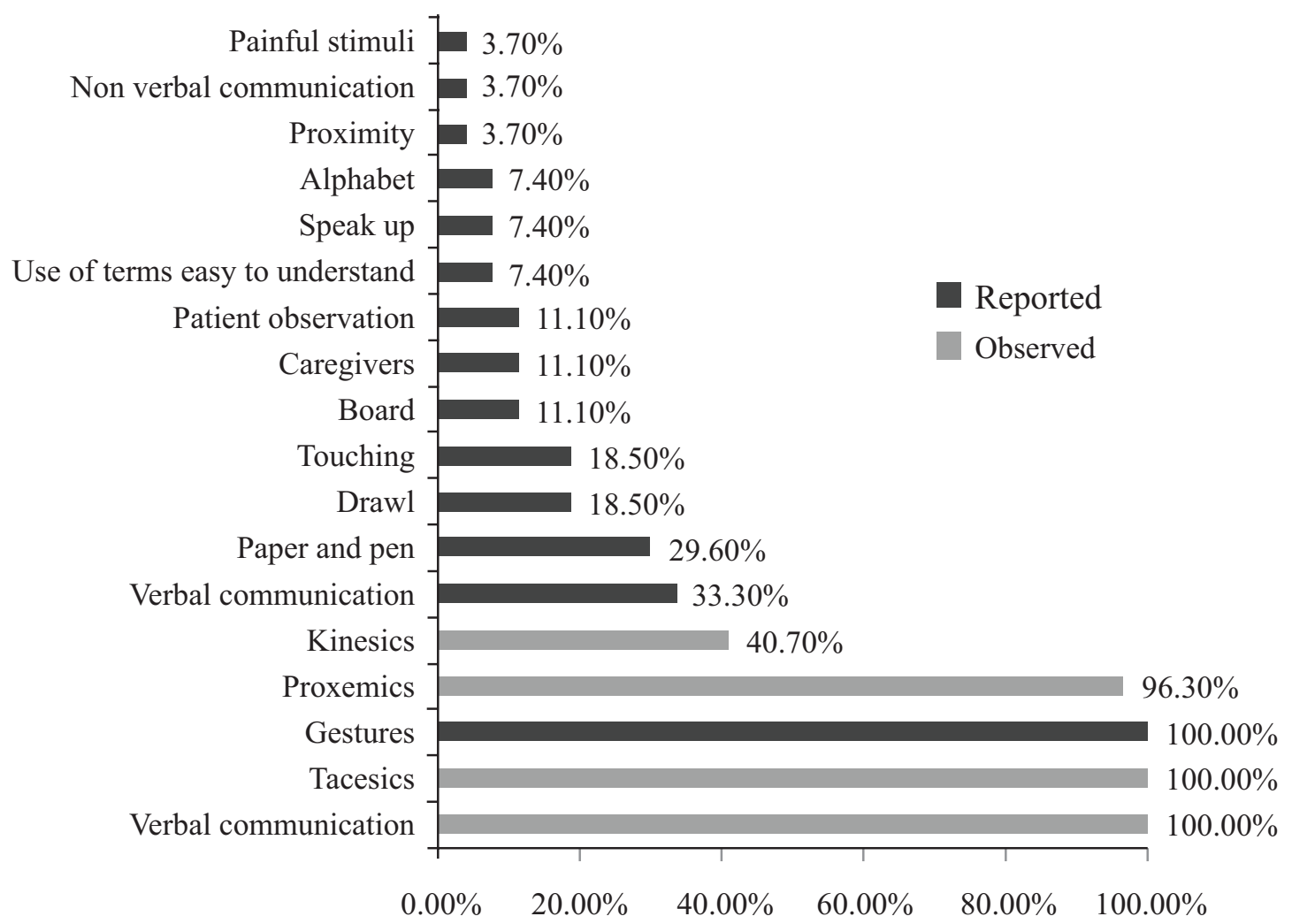

Figure 1 - Reported and observed communication strategies in the care of aphasic patients. São Paulo - SP, Brazil, 2010

\section{DISCUSSION}

The results showed the use of appropriate methodological approaches for the identification of the strategies used in the care of aphasic patients. Confronting the theoretical knowledge related to the strategies of the data from interviews and comparing it with the strategies employed in healthcare has shown a troubling dichotomy in knowing/ using some communication techniques and theoretical ignorance in others. However, the automatism in providing care was evident, showing few initiatives of nonverbal communication and apathy on the part of many patients.

Effective communication between patients who have suffered CVA and the care staff is often not reached due to the resistance of professionals in learning new and more effective methods. However, establishing effective measures in the interaction with these patients brings results with positive impacts in assistance.

It was found that the strategies most reported by professionals were the gestures, verbal communication and paper and pen, with $100 \%, 54.5 \%$ and $50 \%$ respectively. Among the observed strategies, verbal communication, touching and proximity were the most frequent. The strategy of gestures, the most reported by participants, was not frequently present during care, with a percentage of $40.7 \%$. These gestures exert an important role in decoding the messages received during professional or personal interactions ${ }^{(11)}$, and staff should receive guidance regarding its importance to facilitate the process of understanding between those who care and those who are cared for.

The body expressions and manifestations are key elements to the process of communication because of its wide use. In a study carried out with nursing graduate students about the significance of nonverbal communication, gestures and facial expression were most frequently reported symbols in human relations ${ }^{(12)}$. Other authors claim that the tacesics communication (touching) is the most used strategy used in communication with customers, which is consistent with our observation. Although the gestures are more prevalent than touching in the opinion of the participants, the latter constitutes a tool in the observed communication process, but with relevant instrumental character. In addition to the illustrators, no other types of gestures were observed as iconic, regulators and affective.

Regarding the reported strategies in relation to the time of graduation, the gestures are also common, with a greater predominance both among those who have completed their training course within the previous five years as those with more than five years. Among the first, writing communication and drawl are also widely used strategies. Those with longer time since the end of training also use verbal communication, in addition to gestures.

It was found that the sample included young professionals, especially technicians and nursing assistants with 7.8 years of training and 4.8 years of experience with postCVA patients, characteristics that do not seem to affect 
the results of an effective communication. The literature states that there is no evidence linking the time of experience with a better communication performance ${ }^{(10)}$ however, there is evidence confirming that the experience facilitates the communication with people with disabilities to communicate ${ }^{(6)}$. This leads to the reflection that communication is a skill that is not developed and/or required in training courses of the health field. This situation tends to change, because the current emphasis is on developing this type of professional competence, given the demand for appropriate relationships with people in their various contexts of life. This ability has been included in the definition of occupational profiles and curricula, nurses in especial, a minority in the sample of this study.

The proxemics communication - present in all interactions observed among the study subjects - was reported by nursing students as the main influence of nonverbal communication during nursing care ${ }^{(13)}$. The major use of this type of communication is justified by the need to approximate nurses and clients, which is an essential part of the interpersonal relationship in the therapeutic process $^{(13)}$. However, it has to be taken into consideration that the observed care could bias the assessment of this variable because it is impossible that the professional performs it without being near the patient. The way professionals occupy a space that, from the point of view of the territory, belongs to patients demands that they have the knowledge to avoid that the subjects of their actions do not feel inappropriately invaded ${ }^{(14)}$. This is the point when the use of appropriate communication techniques can ensure the differential that nursing actions need to achieve.

The tacesics communication was present in all observed activities and equally occurred because it is related to the implementation of procedures. This type of communication involves the use of hands and if properly used, it allows a more humanized care ${ }^{(13)}$. As already expressed in this study, the use of this communication during care can be classified as instrumental touch because it was the kind of touch required for the development of techniques, not objectifying other purposes. This fact implies that professionals have implemented the resource without awareness of its importance and indication on the client-professional relationship, which is in agreement with the study that observed predominance of instrumental touch over the instrumental-affective and affective ${ }^{(15)}$. The authors of the mentioned study attested that nursing professionals should understand that the process of care is also a form of nonverbal communication. Despite these data, in another observational study ${ }^{(16)}$ it was found that practitioners are aware of the importance of the touch to provide a quality care, in contrast to the findings of this research, in which this was reported by less than one-fifth of the subjects.

The differences observed between the data from semi-structured interviews and field observation may be related to the fact that verbal communication is not important in the conception of professionals and also because they do not have knowledge based on communication, since they reported not having received this particular content during their professional development. In a recent study on factors that influence the communication between patients with communication disability and health professionals, the knowledge about the issue and communication skills were mentioned. Thus, the lack of concern and knowledge of non-verbal communication strategies make it impossible to establish effective communication with these patients ${ }^{(17)}$.

These aspects are important because the complexity imposed by the care to aphasic patients implies in support to professionals. These professionals need special attention from academic and health care institutions when facing difficult situations in providing the care. The knowledge and development of skills are needed in these situations, as well as the support and existence of institutional policies and processes ${ }^{(11)}$. Offering an environment conducive to therapeutic communication associated with training, family involvement, an appropriate physical environment, and attitudes of professionals is essential to establish a proper communication ${ }^{(18)}$. A research carried out with people with aphasia showed that they communicate better with professionals who have been properly trained ${ }^{(19)}$.

This study had some limitations that may have influenced the results. The first was that the researcher was not part of the studied nursing team, which may have influenced the data collection during the observation period. Although the study objectives were very clear to the participants and they seemed secure and apparently available in the answers during the interview, they also seemed bothered by the fact of being watched. This might have led them not to use resources that they habitually use in their daily practice.

It is suggested that further studies are carried out, including the observation of professional-patient interaction in times of referrals for exams, preparation for discharge and other non-routine situations. In addition to studies with greater availability of time of researchers and associating difficulties with the degree of injury, neurological deficit, type of aphasia and evaluation of the emotional state of the patient after the CVA.

Despite the aforementioned limitations, this study provided an opportunity to reflect on the role of nursing professionals regarding the lack of instrumentation on communication techniques. The difficulty in communicating with patients with aphasia after a CVA reflects the lack of training and education programs for health professionals.

Although considered a basic tool of nursing, communication should be seen as a capacity to be developed by nurses, regardless of their area of expertise. Through this
Communication strategies of the nursing team in the aphasia after cerebrovascular accident Souza RCS, Arcuri EAM 
ability it is possible to identify, understand and contribute to solve the problems of patients and their families.

\section{CONCLUSION}

No significant differences were observed between occupational categories depending on the length of experience in relation to the strategies mentioned by members of the nursing staff in the care for aphasic patients. The observed strategies are opposed to those reported in frequency and quality, having noted a diversity of resources that facilitate communication in the interviews (although at low frequencies), but its use has not been observed in practice.

The tacesics and proxemics nonverbal communications were observed because the nursing care required instrumental touching and proximity to patients, which makes the evaluation of its use complex and debatable.

Communication strategies used by nursing staff with aphasic patients are applied informally, without proper knowledge of professionals and without efforts to achieve a more therapeutic communication.

\section{REFERENCES}

1. Bejot Y, Benatru I, Rouaud O, Fromont A, Besancenot JP, Moreau $\mathrm{T}$, et al. Epidemiology of stroke in Europe: geographic and environmental differences. J Neurol Sci. 2007;262(1-2):85-8.

2. Bonita R, Beaglehole R. Stroke prevention in poor countries: time for action. Stroke. 2007;38(11):2871-2.

3. Falcão IV, Carvalho EMF, Barreto KML, Lessa FJD, Leite VMM. Acidente vascular cerebral precoce: implicações para adultos em idade produtiva atendidos pelo Sistema Único de Saúde. Rev Bras Saúde Matern Infant. 2004;4(1):95-102.

4. Hilari K, Needle JJ, Harrison KL. What are the important factors in health-related quality of life people with aphasia? A systematic review. Arch Phys Med Rehabil. 2012;93(1 Suppl):S86-95.

5. Engelter ST, Gostynski M, Papa S, Frei M, Born C, Ajdacic-Gross $\mathrm{V}$, et al. Epidemiology of aphasia attributable to first ischemic stroke: incidence, severity, fluency, etiology, and thrombolysis. Stroke. 2006;37(6):1379-84.

6. Pontes AC, Leitão IMTA, Ramos IC. Comunicação terapêutica em enfermagem: instrumento essencial do cuidado. Rev Bras Enferm. 2008;61(3):312-8.

7. Caron OAF, Silva IA. Parturiente e equipe obstétrica: a difícil arte da comunicação. Rev Latino Am Enferm. 2002;10(4):485-92.

8. Lam JM, Wodchis WP. The relationship of 60 disease diagnoses and 15 conditions to preference -based health-related quality of life in Ontario hospital-based long term care residents. Med Care. 2010;48(4):380-7.

9. Schneider CC, Bielemann VLM, Sousa AS, Quadros LCM, Kantorski LP. Comunicação na unidade de tratamento intensivo, importância e limites- visão da enfermagem e familiares. Cienc Cuid Saúde. 2009;8(4):531-9.

10. Finke EH, Light J, Ketko L. A systematic review of the effectiveness of nurse communication with patients with complex communication needs with a focus on the use of augmentative and alternative communication. J Clin Nurs. 2008;17:2102-15.
11. Silva LMG, Brasil VV, Guimarães HCQCP, Savonitti BHRA, Silva MJP. Comunicação não verbal: reflexões acerca da linguagem corporal. Rev Latino Am Enferm. 2000;8(4):52-8.

12. Santos CCV, Shiratori K. A influência da comunicação não verbal no cuidado de enfermagem. Rev Bras Enferm. 2005;58(4):434-7.

13. Silva MJP. Percebendo o ser humano além da doença: o não verbal detectado pelo enfermeiro. Nursing (São Paulo). 2001;4(41):14-20.

14. Prochet TC, Silva MJP. Proxêmica: as situações reconhecidas pelo idoso hospitalizado que caracterizam sua invasão do espaço pessoal e territorial. Texto Contexto. 2008;17(2):321-6.

15. Pinheiro EM, Rocha IF, Silva MCM. Identificação dos tipos de toque ocorridos no atendimento de enfermagem de um serviço ambulatorial. Rev Esc Enferm USP. 1998;32(3):192-8.

16. Gala MF, Telles SCR, Silva MJP. Ocorrência e significado do toque entre profissionais de enfermagem e pacientes de uma UTI e unidade semi-intensiva cirúrgica. Rev Esc Enferm USP. 2003;37(1):52-61.

17. O'Halloran R, Grohn B, Worrall L. Environmental factors that influence communication for patients with a communication disability in acute hospital stroke units: a qualitative metasynthesis. Arch Phys Med Rehabil. 2012;93(1 Suppl):S77-85.

18. O'Halloran R, Worrall L. Environmental factors that influence communication between patients and their healthcare providers in acute hospital stroke units: an observational study. Int J Lang Commun Disord. 2011;46(1):30-47.

19. Simmons-Mackie NN, Cristie CO, Kagan A, Huijbregts $M$, McEwen, Willems J. Communicative access and decision making for people with aphasia: implementing sustainable healthcare systems change. Aphasiology. 2007;21(1):39-66. 